them as individuals, which was right and proper. The organizers have larded their ban with varying expressions of regret that the course they have felt compelled to follow will interfere with the free flow of ideas in science (and also infringe the statutes of IUPPS). There is wide sympathy for the position in which they find themselves, having to choose between the application of a principle they espouse and their understandable wish not to see months of careful planning wasted, perhaps at substantial cost. But there is no basis on which a group of scholars can exclude from an otherwise public meeting people who are qualified to attend, but whose government is socially unjust. To be the first in the field is a dubious distinction.

This is where the case of Dr Sakharov is relevant. Sakharov was an outspoken critic of the Soviet system a decade ago. He has not been charged with criminal activities, but merely sent to live in isolation from his friends and colleagues. Senior members of the Soviet academy say that Sakharov has been dealt with leniently, given the sharpness of his criticisms, but to their credit they have not expelled him from the academy, which would remove both his salary and his present degree of protection from administrative harassment. Even so, the case of Sakharov, like those of many other Soviet citizens who have suffered harsh administrative and legal penalties, has clouded scientific collaboration between Western and Soviet institutions. Yet at no stage has it been seriously suggested in the West that Soviet scientists as such are not welcome in the international community. If anything, the decay of formal collaboration has intensified the sense of loss that Soviet colleagues are absent from meetings at which they would naturally be found. Mercifully, but inconsistently, Soviet scientists have not been banned from Southampton. So why pick on South Africans?

The organizers say they have no choice, but they are wrong. Those who arrange meetings are always free to cancel them. Far better to stomach the embarrassment of wasted advertising literature than to be the first to introduce the principle of discrimination on the grounds of nationality into the conduct of intellectual affairs. Unless something can be done to make this congress respectable, it will probably be a tarnished affair, not merely on account of the notoriety it has attracted but because of the numbers of people who are threatening to stay away in sympathy with the handful of South Africans who will be excluded. The executive committee of IUPPS should bite the bullet and appeal to other scientific unions for help with the money problems left over.

Meanwhile, others must worry about the damage already done. The reputation of British academic institutions will have been harmed by this general advertisement of the power of campus demagogues, students and, lamentably, teachers. Does this mean that South Africans will be banned from all future international meetings in Britain? Does AUT's famous national policy deliberately invite this consequence, or is it merely a licence for local initiative by sporadic vigilantes? In their own interests, British academics should insist that the position of their representative body is clarified. AUT rightly spends most of its energy on academic pay and conditions of service, but its annual conferences may also adopt resolutions on more general matters. AUT's policy on South Africa is badly thought out.

More generally, there are international forces to be reckoned with. Although the constitution of IUPPS itself is explicitly non-discriminatory, the union is affiliated to UNESCO, which adopted a policy of deliberate discrimination against South Africans four years ago. Does that make sense? There is a more sinister threat in the statement by one of the Southampton organizers that it is no longer possible to organize an international conference to which "third world" scientists are invited without discriminating against South Africans. That cannot be the whole truth (witness the attendance of several South African astronomers at last December's meeting of the International Astronomical Union in Delhi), but even if it were a part of the truth, it would be a bad business for us all.

\section{Chopper politics}

The British government seems bent on making a muddle of its policy on helicopter manufacture.

WESTLAND, a small manufacturer of helicopters based in southwest England, has become the centre of a bewildering row between British cabinet ministers for all the wrong reasons, which between them should provide a salutary warning for high-technology industries dependent on defence departments for their survival. The troubles stem from the nature of the helicopter as a means of transport. Although it was once commonly supposed that such machines had a bright future as means of almost personal transport, experience has shown them to be an expensive means of getting about, uncompetitive with fixedwing aircraft over distances much greater than 100 kilometres and with surface transport over shorter distances. The only civil markets for the machines that matter are tiny, and are confined to circumstances where other means of transport do not exist (as in the servicing of oil-rigs at sea) or where a few minutes saved on a journey time may command a high price. (There is still a market for helicopter journeys between New York's principal international airport and Manhattan.) Otherwise, the helicopter has become almost exclusively a military vehicle, a means of transport and a battle-station.

Westland has known this for some time. For the past year, it has been pleading with the British Ministry of Defence under $\mathrm{Mr}$ Michael Heseltine for extra projects on which to work, and has been refused. So, under pressure from its bankers, Westland has been seeking larger companies willing to mount what is called in the trade a "rescue". The US corporation United Technologies, which owns Sikorski, another helicopter manufacturer, in conjunction with Italian Fiat, was the first in the field. Mr Heseltine has since organized a bid from a European consortium of aircraft manufacturers which differs chiefly in the amount of employment it offers the labour force at Westland. Members of the British cabinet have fallen out among themselves because some (including the Prime Minister) rightly say that the company should decide on commercial ground which bid to accept, while Mr Heseltine (who is not alone) threatens that Westland will not again win European orders for helicopters unless it accepts the bid he has organized (which it is within the power of European governments to ensure).

The piquancy of the resulting row derives from its bearing on British domestic politics. What the participants have forgotten is that Westland's problems of a year ago were a sign that there were then more helicopter manufacturers than the world's defence ministries could employ. Nothing much seems to have changed since then. And nothing has happened to suggest that Westland's technical dependence on other manufacturers (Sikorski in particular) will have been replaced by technical adventurousness in an admittedly difficult field. Mr Heseltine's European bid smells too much of an attempt to keep in being a company that is otherwise not viable by means of a redistribution of helicopter work among European governments.

The lesson to be learned from this should in reality have been learned a long time ago. The prizes now go to those who make technically advanced products of high quality. In civilian markets, to be second or third best is to invite disaster, but in the military field, chauvinism can keep projects afloat for longer than logic would allow. The fate of Westland has become an issue largely because the British government has resolved to let economic logic apply more rigorously than will other European governments. Mr Heseltine's laudable ambition that European defence forces should have access to the best equipment could just as well be satisfied by letting Westland go to the highest bidder and, quite separately, planning with European governments a strategy for buying (not necessarily making) the next generation of military helicopters. That way, he would discover, British taxpayers would find themselves paying less. 